\title{
Pengaruh Ekstrak Etanol Lidah Buaya (Aloe Vera) Terhadap Glukosa Darah Tikus Hiperglikemia- Terinduksi Streptozotocin
}

\author{
Halia Wanadiatri ${ }^{1}$, Achmad Basori ${ }^{2}$, I Ketut Sudiana 3 \\ ${ }^{1}$ Mahasiswa Ilmu Kedokteran Dasar Jenjang Magister, Fakultas Kedokteran \\ Universitas Airlangga Surabaya \\ 2 Departemen Farmakologi, Fakultas Kedokteran, Universitas Airlangga \\ 3 Departemen Patologi Anatomi, Fakultas Kedokteran, Universitas Airlangga \\ e-mail : haliawanadiatri@gmail.com
}

\begin{abstract}
ABSTRAK
Diabetes Mellitus (DM) merupakan penyakit kronik dengan prevalensi nasional 6,9\% pada tahun 2013. Hiperglikemia merupakan karakteristik dari penyakit DM. Pengobatan antidiabetes memiliki beberapa efek samping, seperti peningkatan berat badan, hipoglikemia, toksisitas hepar dan ginjal. Beberapa penelitian sebelumnya membuktikan bahwa ekstrak etanol lidah buaya dapat menurunkan kadar glukosa darah, namun mekanisme penurunan glukosa darah masih belum jelas. Penelitian ini merupakan penelitian eksperimental, menggunakan 35 ekor hewan coba, dibagi dalam 5 kelompok yaitu kelompok kontrol normal, kontrol hiperglikemia, kelompok perlakuan yang diberi dosis ekstrak etanol lidah buaya bertingkat, diadaptasikan selama 14 hari kemudian diinduksi dengan injeksi STZ. Kelompok perlakuan diberikan ekstrak etanol lidah buaya sesuai dengan dosis tiap kelompok selama 21 hari personde intragastrik. Pemeriksaan BSN dan GD2PP menggunakan glukometer terkalibrasi. Data dianalisa dengan Kruskal-Wallis, dilanjutkan dengan Mann-Whitney. Hasil uji komparasi meunjukkan bahwa terdapat perbedaan bermakna antar kelompok $(p<0,05)$ pada variabel $\triangle B S N-2 P P$. Dosis $250 \mathrm{mg} / \mathrm{kgBB}$ memiliki efek yang lebih baik terhadap penurunan kadar glukosa darah.
\end{abstract}

Kata kunci : Ekstrak etanol lidah buaya, kadar glukosa darah, streptozotocin, sel otot rangka. 


\section{PENDAHULUAN}

Diabetes Mellitus (DM) merupakan penyakit kronis yang terjadi saat pankreas tidak memproduksi insulin yang cukup atau saat tubuh tidak dapat menggunakan produksi insulin secara efektif (Reza et al., 2017). DM memiliki karakteristik hiperglikemia yang dihasilkan dari defisiensi insulin sepenuhnya atau kurangnya sekresi insulin dan/atau sensitifitas insulin. Penelitian epidemiologi dan percobaan klinis menunjukkan bahwa hiperglikemia merupakan prinsip dasar terjadinya komplikasi (Noor et al., 2017). DM merupakan penyebab kematian ketiga setelah stroke dan hipertensi (Kemenkes RI, 2011). Prevalensi nasional Diabetes Mellitus di Indonesia pada tahun 2007 sebesar 5,7\% dan meningkat menjadi $6,9 \%$ pada tahun 2013 berdasarkan pemeriksaaan gula darah pada penduduk $>15$ tahun di perkotaan (Kemenkes RI, 2014).

WHO memperkirakan bahwa lebih dari $80 \%$ masyarakat masih mengandalkan pengobatan tradisional. Faktanya, banyak obat-obatan sekarang meniru sebagian atau keseluruhan struktur molekuler alamiah tanaman (Joseph \& Raj, 2010). Etnofarmakologi mengembangkan penggunaan tanaman obat untuk terapi Diabetes Mellitus karena biaya yang rendah, mudah didapatkan, dan sedikit efek sampingnya (Beidokhti \& Jäger, 2017).

Lidah buaya atau Aloe vera termasuk famili Liliaceae. Asal tanaman ini banyak berasal dari daerah seperti Afrika, Asia, dan Eropa Selatan, khususnya regio Mediterania (Rodríguez-González et al.,2011). Pada penelitan-penelitian sebelumnya, acemannan, antraquinon dan phytosterol diduga memiliki efek antidiabetes (AlinejadMofrad et al., 2015; Cowsert, 2010; Tanaka et al., 2006). Acemannan, antraquinon dan phytosterol ditemukan di Aloe vera yang diduga memiliki efek antidiabetes, namun mekanisme penurunan kadar glukosa darah pada pemberian ekstrak etanol lidah buaya (Aloe vera) belum jelas.

Berdasarkan hal tersebut, penelitian ini dilakukan untuk mengetahui pengaruh ekstrak etanol lidah buaya (aloe vera) terhadap glukosa darah pada tikus hiperglikemia-terinduksi streptozotocin, karena pada penelitian terdahulu pengaruh ekstrak etanol lidah buaya terhadap kadar glukosa darah pada tikus hiperglikemia belum jelas.

\section{METODE PENELITIAN}

Penelitian ini adalah penelitian True Eksperimental Laboratories dengan rancangan Posttest Control Group Design. Dalam penelitian ini digunakan hewan coba 35 ekor yang dibagi dalam 5 kelompok perlakuan masing-masing 7 ekor yaitu kelompok kontrol normal (KN), kontrol hiperglikemia $(\mathrm{KH})$, kelompok perlakuan yang diberi ekstrak etanol lidah buaya 250 $\mathrm{mg} / \mathrm{kgBB}$ (K1), kelompok perlakuan yang diberi ekstrak etanol lidah buaya 300 $\mathrm{mg} / \mathrm{kgBB}$ (K2), kelompok perlakuan yang diberi ekstrak etanol lidah buaya 350 $\mathrm{mg} / \mathrm{kgBB}$ (K3). Kriteria inklusi pada hewan coba tikus putih (Rattus novergicus) galur wistar yaitu berusia 2-3 bulan, berat badan 150-200 gram, dalam kondisi sehat, jenis kelamin jantan, hiperglikemia pada kadar glukosa darah puasa diatas $126 \mathrm{mg} / \mathrm{dL}$ (Jung Ji Young et al., 2011; Damasceno et al., 2014).

Penelitian ini dilakukan di Unit Hewan Coba Laboratorium Farmakologi dan Terapi Fakultas Kedokteran Universitas Airlangga. Waktu penelitian dilakukan pada bulan Maret-April 2018. Variabel pada penelitian ini terdiri dari variabel bebas, variabel terikat, dan variabel kendali. Variabel bebas yaitu pemberian dosis ekstrak etanol lidah buaya $(250 \mathrm{mg} / \mathrm{kgBB}$, $300 \mathrm{mg} / \mathrm{kgBB}$, dan $350 \mathrm{mg} / \mathrm{kgBB}$ ). Variabel tergantung yaitu kadar glukosa darah puasa/blood sugar nucter (GDP/BSN) dan kadar glukosa darah 2 jam postprandial (GD2PP). Variabel kendali antara lain cara induksi hewan coba, dosis ekstrak etanol lidah buaya, waktu evaluasi, kesehatan fisik hewan coba, berat badan hewan coba (gr), pemeliharaan dan perawatan hewan coba. Ekstrak etanol lidah buaya diolah di Materia Medika Batu-Malang, dengan metode maserasi. Tikus dibuat dalam kondisi hiperglikemia dengan induksi pemberian 
injeksi streptozotocin (STZ) per intraperitoneal dengan dosis $40 \mathrm{mg} / \mathrm{kgBB}$ sebanyak satu kali. Sebelum induksi STZ, tikus dipuasakan selama 12 jam, minum tetap diberikan. Setelah diinduksi, ditunggu selama 72 jam untuk menilai kadar glukosa darah puasa tikus. Pasca pemberian suntikan STZ, untuk menghindari efek samping dan resiko terjadinya sudden hypoglycemic maka diberi larutan sukrosa atau dekstrosa $10 \%$ sepanjang malam (Purwanto et al., dalam Wibisono, 2016), dan diberikan air minum dua kali lebih banyak dari sebelumnya, guna mencegah dehidrasi. Kebersihan kandang diperhatikan. Tikus dengan kadar glukosa darah lebih dari 120 $\mathrm{mg} / \mathrm{dl}$ digunakan untuk penelitian pada kelompok perlakuan dan kontrol hiperglikemia (Damasceno et al., 2014).

Lima kelompok ini setelah masa aklimatisasi selama 2 minggu, pada hari pertama dilakukan kadar GDP awal untuk menilai hewan coba berdasarkan kriteria inklusi. STZ disuntikkan intraperitoneal dengan dosis $40 \mathrm{mg} / \mathrm{kgBB}$ pada kelompok $\mathrm{KH}, \mathrm{K} 1, \mathrm{~K} 2$, dan K3. Hari keempat GDP post STZ di periksa kembali untuk melihat status hiperglikemia, hewan coba pada keempat kelompok tersebut berstatus hiperglikemia $(>126 \mathrm{mg} / \mathrm{dl})$. Hari ke-40 (akhir penelitian), GDP post ekstrak di periksa kemudian diberi beban glukosa $2 \mathrm{mg} / \mathrm{grBB}$, dan setelah 2 jam glukosa darah di periksa kembali (GD2PP), hal ini untuk mengetahui profil penurunan glukosa darah dan melihat kemampuan glukosa masuk ke dalam sel pada tikus setelah pemberian ekstrak etanol lidah buaya dengan menggunakan alat glukometer terkalibrasi, dan hasil yang didapatkan pada stik glukometer dikalikan dengan kalibrasi faktor $(0,72)$. Kalibrasi faktor didapatkan dari hasil pengumpulan darah (manusia) sebanyak 5 orang secara acak, yang kemudian darah di periksa menggunakan alat glukometer dan pemeriksaan laboratorium. Hasil yang didapatkan dari pemeriksaan glukometer dibandingkan dengan hasil yang didapatkan dari laboratorium. Pemeriksaan GDP diperoleh dengan menginsisi ekor tikus sekitar 1-2 mm. Seluruh hewan coba dikorbankan pada hari ke 40, setelah dipuasakan 7 jam sebelumnya.
Tabel 1. Data Rerata Kadar GDP dan GD2PP (mg/dl)

\begin{tabular}{|c|c|c|c|c|c|c|}
\hline $\begin{array}{l}\text { Kelo } \\
\text { mpo } \\
\text { k }\end{array}$ & $\mathbf{n}$ & $\begin{array}{l}\text { GDP } \\
\text { awal } \\
(\mathbf{X} \pm \mathbf{S} \\
\text { D) }\end{array}$ & $\begin{array}{l}\text { GDP } \\
\text { post } \\
\text { STZ } \\
(\mathrm{X} \pm \mathbf{S} \\
\text { D) }\end{array}$ & $\begin{array}{l}\text { GDP } \\
\text { post } \\
\text { ekstr } \\
\text { ak } \\
(\mathrm{X} \pm \mathrm{S} \\
\text { D) }\end{array}$ & $\begin{array}{l}\text { GD2 } \\
\text { PP } \\
(X \pm S \\
\text { D) }\end{array}$ & $\begin{array}{l}\Delta \\
\text { BSN- } \\
2 \mathrm{PP} \\
(\mathrm{X} \pm \mathrm{S} \\
\text { D) }\end{array}$ \\
\hline K1 & 7 & $\begin{array}{l}85,29 \\
\pm 15,3 \\
6\end{array}$ & $\begin{array}{l}254,8 \\
6 \pm 79 \\
44\end{array}$ & $\begin{array}{l}116,0 \\
0 \pm 18, \\
81\end{array}$ & $\begin{array}{l}131,7 \\
1 \pm 18, \\
58\end{array}$ & $\begin{array}{l}15,71 \\
\pm 4,6 \\
0\end{array}$ \\
\hline $\mathrm{K} 2$ & 7 & $\begin{array}{l}70,29 \\
\pm 13,4 \\
3\end{array}$ & $\begin{array}{l}222,4 \\
3 \pm 14 \\
68\end{array}$ & $\begin{array}{l}157,1 \\
4 \pm 75, \\
30\end{array}$ & $\begin{array}{l}168,8 \\
6 \pm 74, \\
46\end{array}$ & $\begin{array}{l}11,71 \\
\pm 3,4 \\
0\end{array}$ \\
\hline K3 & 7 & $\begin{array}{l}83,43 \\
\pm 10,7 \\
3\end{array}$ & $\begin{array}{l}284,5 \\
7 \pm 10 \\
4,34\end{array}$ & $\begin{array}{l}203,7 \\
1 \pm 10 \\
0,80\end{array}$ & $\begin{array}{l}225,1 \\
4 \pm 10 \\
5,67\end{array}$ & $\begin{array}{l}21,43 \\
\pm 7,8 \\
9\end{array}$ \\
\hline $\mathrm{KH}$ & 7 & $\begin{array}{l}69,14 \\
\pm 12,0 \\
9\end{array}$ & $\begin{array}{l}377,8 \\
6 \pm 14 \\
3,43\end{array}$ & $\begin{array}{l}321,2 \\
9 \pm 94, \\
39\end{array}$ & $\begin{array}{l}370,8 \\
6 \pm 11 \\
0,68\end{array}$ & $\begin{array}{l}49,57 \\
\pm 24 \\
30\end{array}$ \\
\hline $\mathrm{KN}$ & 7 & $\begin{array}{l}86,71 \\
\pm 10,3 \\
9\end{array}$ & $\begin{array}{l}92,71 \\
\pm 6,42\end{array}$ & $\begin{array}{l}89,86 \\
\pm 5,33\end{array}$ & $\begin{array}{l}101,2 \\
9 \pm 8,3 \\
2\end{array}$ & $\begin{array}{l}11,43 \\
\pm 5,4 \\
4\end{array}$ \\
\hline
\end{tabular}

Keterangan:

$\mathrm{K} 1$ = kelompok perlakuan pemberian ekstrak etanol lidah buaya $250 \mathrm{mg} / \mathrm{kgBB}$

$\mathrm{K} 2$ = kelompok perlakuan pemberian ekstrak etanol lidah buaya $300 \mathrm{mg} / \mathrm{kgBB}$

$\mathrm{K} 3=$ kelompok perlakuan pemberian ekstrak etanol lidah buaya $350 \mathrm{mg} / \mathrm{kgBB}$

$\mathrm{KH}=$ kelompok hiperglikemia

$\mathrm{KN}=$ kelompok normal 


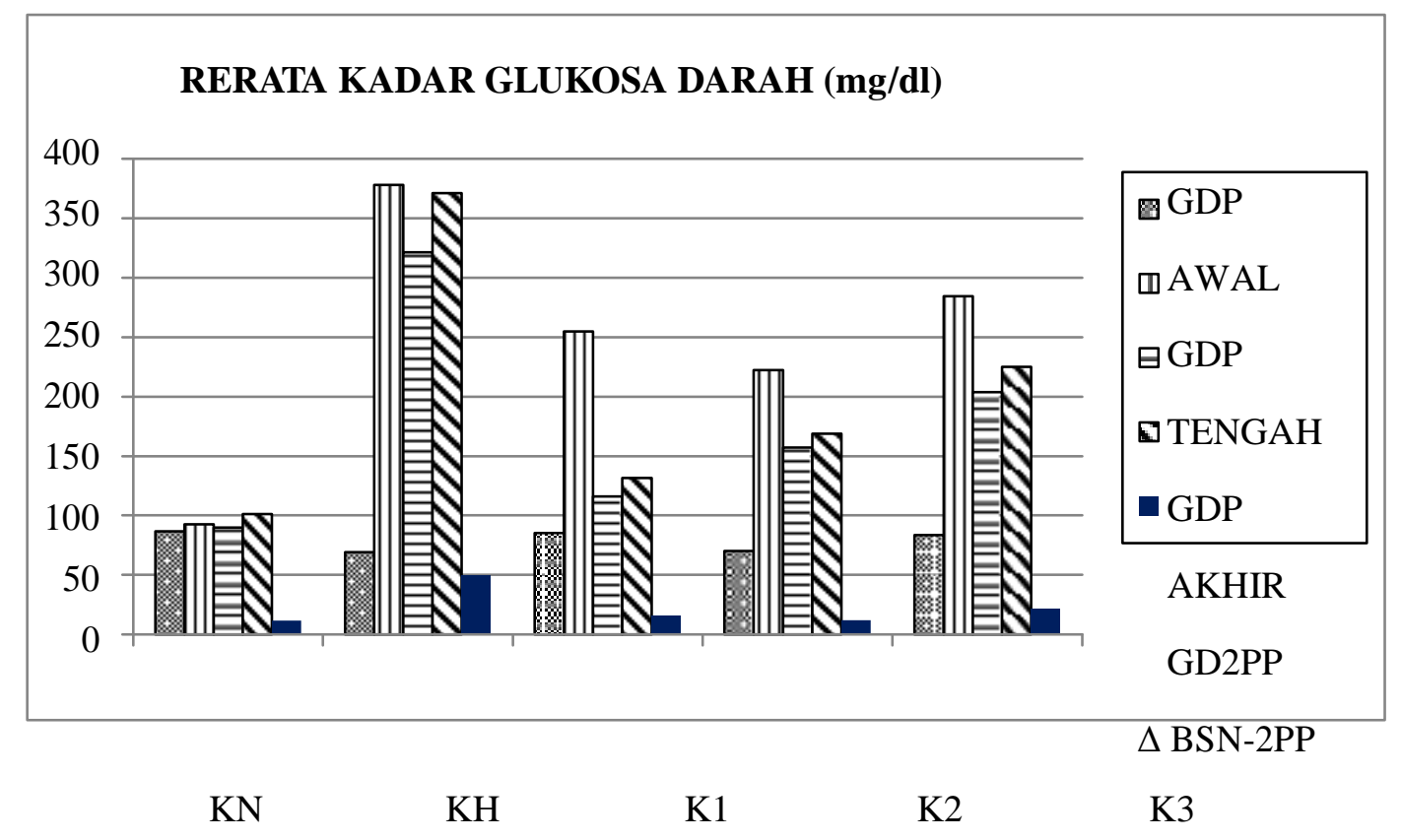

Gambar 1. Data rerata kadar GDP, GD2PP, dan $\triangle$ BSN-2PP pada kelompok $\mathrm{KN}, \mathrm{KH}, \mathrm{K} 1$, K2, dan K3 
Untuk melihat normalitas dan homogenitas data menggunakan uji Komolgorov-Smirnov dan uji Levene. Data yang didapatkan berdistribusi normal $(p>0,05)$ dan tidak homogen $(p<0,05)$. Berdasarkan uji normalitas dan homogenitas tersebut, karena variabel glukosa darah memiliki varian yang tidak sama (tidak homogen), maka yang dinilai adalah variabel delta $(\Delta)$ BSN-2PP (selisih antara kadar GD2PP dengan kadar GDP post ekstrak). Penilaian terhadap $\triangle \mathrm{BSN}$ 2PP berguna untuk melihat seberapa besar peningkatan glukosa darah dari GDP akhir ke GD2PP, hal ini untuk melihat fungsi sel (sel otot) dalam mengambil glukosa darah yang efektif guna menjadi energi bagi sel itu sendiri setelah diberikan ektrak etanol lidah buaya, hal ini memiliki arti bahwa makin tinggi $\Delta$ maka ekstrak etanol lidah buaya memiliki efek antihiperglikemia yang makin bagus. Pada tabel 1 , setelah rerata $\Delta$ BSN2PP didapatkan, kemudian dilakukan kembali uji normalitas dan homogenitas, $\Delta$ BSN-2PP memiliki data berdistribusi normal $(p>0,05)$ dan tidak homogen $(p<0,05)$. Karena data normal dan tidak homogen, maka uji yang dilakukan selanjutnya yaitu uji komparasi dengan uji nonparametrik menggunakan uji Kruskal Wallis. Hasil uji Kruskal Wallis didapatkan hasil bahwa terdapat perbedaan bermakna antar kelompok dengan nilai $\mathrm{p} 0,000 \quad(\mathrm{p}<0,05)$ pada variabel $\Delta \mathrm{BSN}-2 \mathrm{PP}$.

Langkah selanjutnya untuk melihat perbedaan yang signifikan dilakukan uji Mann-Whitney. Pada tabel 2 dapat dilihat ketiga kelompok perlakuan (K1, K2, dan K3) memiliki perbedaan yang bermakna $(\mathrm{p}<0,05)$ dengan kelompok hiperglikemia $(\mathrm{KH})$. Hal ini secara statistik membuktikan bahwa pada kelompok- kelompok perlakuan memiliki nilai $\Delta$ BSN-2PP yang berbeda dengan nilai $\triangle \mathrm{BSN}-2 \mathrm{PP}$ pada kelompok $\mathrm{KH}$, bisa terlihat pada rerata $\Delta \mathrm{BSN}-2 \mathrm{PP}$ masing- masing kelompok perlakuan yang dibawah rerata $\Delta \mathrm{BSN}-2 \mathrm{PP}$ kelompok $\mathrm{KH}$, dan juga tampak perbedaan yang bermakna pada kelompok $\mathrm{KH}$ dengan kelompok KN. Pada kelompok perlakuan K1 dan K2 tidak didapatkan perbedaan yang bermakna $(p>0,05)$ dengan kelompok KN, tampak nilai rerata $\Delta$ BSN-2PP pada kelompok K1 dan K2 mendekati nilai normal rerata pada kelompok KN. Namun pada kelompok K3 terdapat perbedaan yang bermakna $(\mathrm{p}<0,05) \quad$ terhadap kelompok K2 dan $\mathrm{KN}$ (p K2 K3=0,009) (p $\mathrm{K} 3 \sim \mathrm{KN}=0,015$ ), hal ini dapat dilihat dari rerata $\Delta \mathrm{BSN}-2 \mathrm{PP}$ yang cukup berbeda pada masing-masing kelompok tersebut (rerata $\mathrm{K} 2=11,71 \pm 3,4$, $\mathrm{K} 3=21,43 \pm 7,89$, $\mathrm{KN}=11,43 \pm 4,44)$.

Tabel 2. Hasil uji Mann-Whitney variabel $\Delta \mathrm{BSN}-2 \mathrm{PP}$

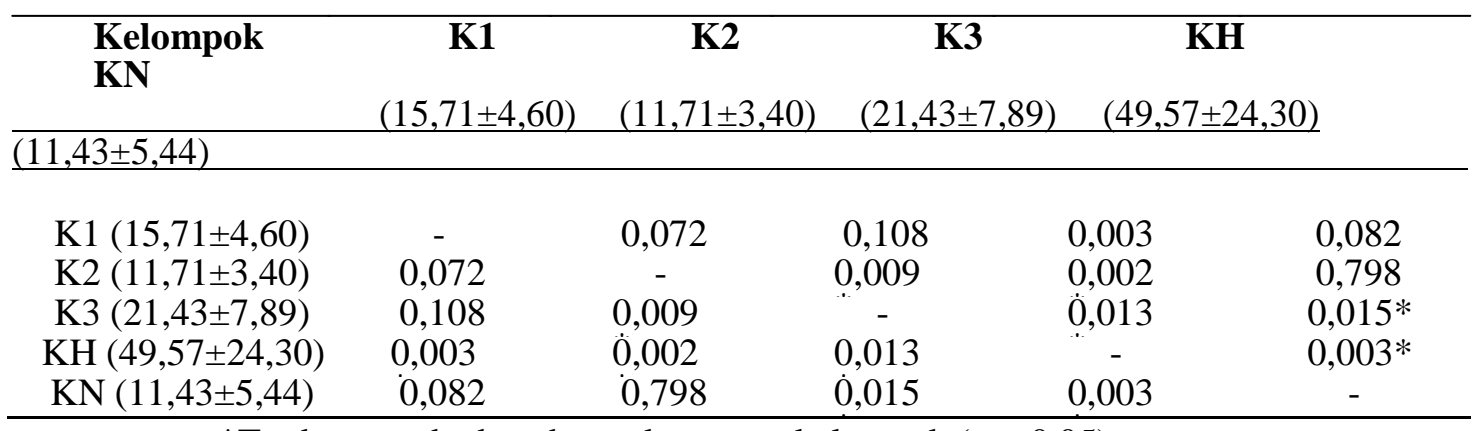

*Terdapat perbedaan bermakna antar kelompok $(\mathrm{p}<0,05)$

Kemudian untuk mengetahui hubungan dosis respon dilakukan dengan uji regresi linier sederhana. Tujuan analisis regresi adalah untuk membuat perkiraan (prediksi) nilai suatu variabel (variabel dependen) melalui variabel yang lain (variabel independen) (Hastono S.P. et al., 2011). 
Tabel 3. Hasil Analisa Regresi Linier Variabel $\Delta$ BSN-2PP

\begin{tabular}{cc}
\hline Variabel & Hasil Analisis Regresi \\
\hline$\Delta$ BSN-2PP & $\mathrm{p}=0,000$ \\
$\mathrm{R}=0,699$ \\
$\mathrm{R}^{2}=0,488$ \\
$\mathrm{~B}=-0,099$ \\
$\mathrm{~B}$ constant $=49,963$ \\
Beta $=-0,699$ \\
thit $=-4,979$ \\
\hline
\end{tabular}

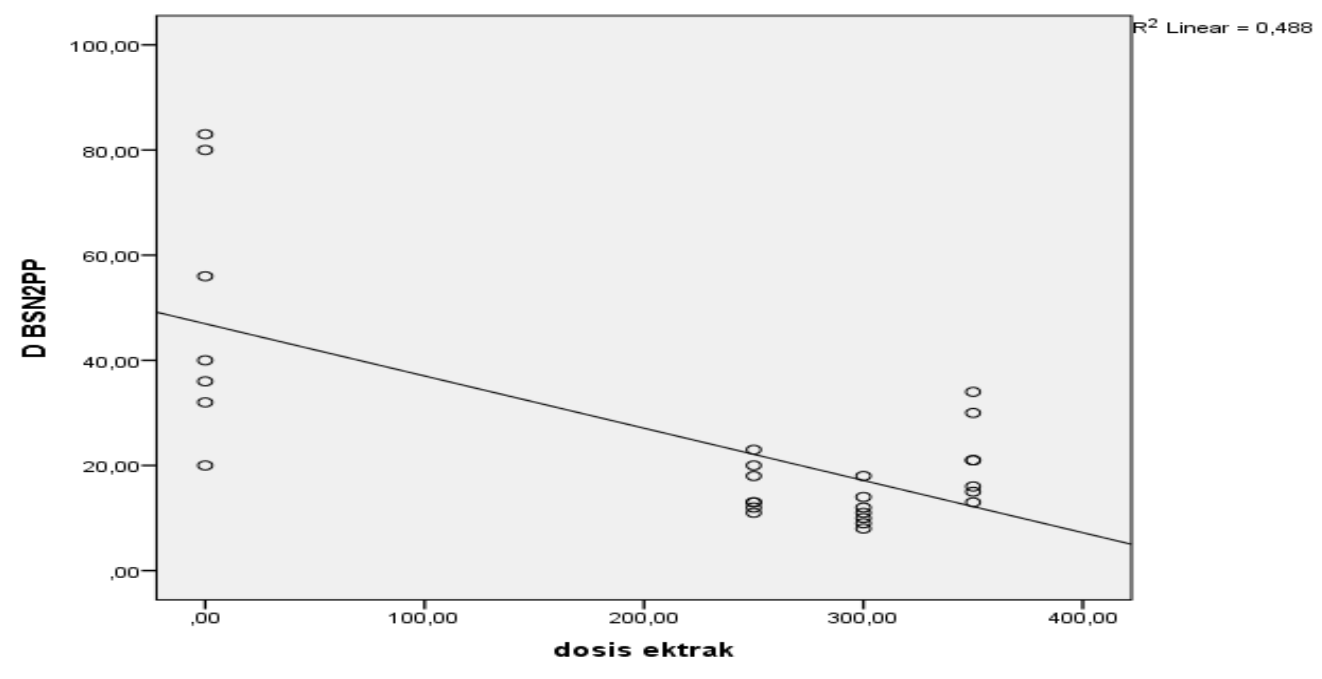

Gambar 2 Kurva Liniearitas Dosis-Respon Estrak Etanol Lidah Buaya Terhadap Penurunan Glukosa Darah 


\section{PEMBAHASAN}

Glukosa dianggap sebagai bahan bakar utama untuk energi dan dianggap sebagai bahan awal untuk hampir semua varietas reaksi biosintetik. Dengan demikian, konsentrasi glukosa yang tepat sangat diperlukan untuk menjamin fungsi dan kelangsungan hidup yang tepat dari setiap sel, jaringan dan organ. Tingkat glukosa darah secara signifikan mengatur tingkat pelepasan insulin. Glukosa juga memiliki mekanisme negatif feedback pada pelepasan insulin, guna mengurangi sekresi insulin bila kadar glukosa darah sudah normal kembali. Sekresi insulin memiliki fase bipashic; pada fase pertama, kadar insulin mencapai kadar tertingginya setelah 1-2 menit namun dalam jangka waktu pendek, sementara sekresi insulin pada fase selanjutnya onsetnya lambat namun periodenya lama. Gangguan atau tidak tepatnya metabolisme glukosa dapat menyebabkan masalah fisiologis (Sen S. et al., 2016).

Mekanisme hemostasis glukosa pada kondisi basal atau postabsorbtive (10-

12 jam puasa semalaman) dan diikuti konsumsi makanan yang khusus. Pada keadaan postabsorbtive mayoritas penyebaran glukosa tubuh total terjadi di jaringan independent insulin, sekitar 50\% dari semua penggunaan glukosa terjadi di otak, yang dimana insulin-independent dan menjadi jenuh pada konsentrasi glukosa plasma sekitar $40 \mathrm{mg} / \mathrm{dl}$. Lainnya $25 \%$ penyebaran glukosa terjadi di area splanknik (hati dan jaringan gastroinstestinal), yang mana juga merupakan jaringan insulin-independent. Sisanya $25 \%$ glukosa digunakan pada keadaan postabsorbtive pada jaringan insulindependent, terutama otot, dan jaringan adiposa. Sekitar $85 \%$ produksi glukosa endogen berasal dari hepar, dan sisanya $15 \%$ diproduksi di ginjal. Glikogenolisis dan glukoneogenesis berkontribusi sama dengan tingkat basal produksi glukosa di hepar (DeFronzo R.A.,2004).

Hiperglikemia pada DM tipe 2 berkembang sebagai akibat dari sekresi insulin yang tidak adekuat bersamaan dengan resistensi perifer terhadap aksi insulin. Pada tahap awal penyakit, ada penundaan dan ketidakcukupan sekresi insulin fase awal sebagai respon terhadap glukosa yang mengakibatkan hiperglikemia setelah pembebanan glukosa (toleransi glukosa terganggu). Setelah itu kerusakan fungsi sel menjadi progresif yang mengarah ke gangguan hemostasis glukosa antara kadar glukosa darah puasa dan posprandial akhirnya berkembang (Soonthornpun, 1999).

Pemberian ekstrak lidah buaya yang memiliki zat-zat aktif yang berpotensi sebagai antidiabetik yaitu acemannan, antraquinon dan phytosterol. Zat-zat aktif ini diduga memiliki pengaruh dalam menurunkan glukosa darah dengan meningkatkan GLUT4 melalui jalur aktivasi PI3K (phosphatidylinositol 3kinase), pengaktifan jalur PI3K ini akan menfosforilasi PI2P (phosphatidylinositol

4,5 biphosphate) menjadi PI3P (phosphatidylinositol 3,4,5 triphosphate). PI3P yang teraktivasi ini akan meningkatkan PDK 1 (3-phosphoinositidedependent protein kinase), kemudian akan mengaktivasi Akt. Akt yang teraktivasi inilah yang dapat menginduksi translokasi GLUT4 dari GLUT4 containing vesicle menuju membran sel, sehingga GLUT4 yang berada di membran sel dapat menangkap glukosa dari luar (darah) dan membawa glukosa masuk ke dalam sel otot, yang mana otot skelet merupakan organ manusia terbesar yang sensitif terhadap insulin yang mencapai $85 \%$ dari ambilan glukosa seluruh tubuh dan memegang peranan penting dalam menjaga hemostasis glukosa sistemik (Revathy et al., 2015).

Pada penelitian ini yang diperiksa untuk menandakan status hiperglikemia yaitu dengan kadar glukosa darah puasa, dan juga menilai kadar glukosa 2 jam post prandial yang dapat mencerminkan absorbsi karbohidrat, sekresi insulin dan glukagon, dan koordinasi keduanya dalam metabolisme glukosa di hati dan jaringan perifer seperti otot, sehingga glukosa dapat masuk ke dalam sel otot dan dapat digunakan sebagai sumber energi yang efektif dalam metabolisme tubuh. Induksi hiperglikemia pada hewan coba menggunakan STZ pada tingkat seluler dapat menyebabkan kegagalan oksidasi glukosa dan mengurangi biosintesis dan 
sintesis insulin. Hasil dari paparan STZ dapat menyebabkan sel beta kehilangan respon terhadap glukosa (Karunakaran, et al., 2015). Hal ini sesuai dengan penelitian yang menunjukkan bahwa pemberian injeksi STZ dapat menginduksi terjadinya hiperglikemia, dan bila dilihat dari nilai rerata pada kelompok KH (tabel 1) yang tidak diberikan terapi memiliki nilai rerata tertinggi.

Dari data tersebut dapat dilihat bahwa efek pemberian ekstrak etanol lidah buaya pada dosis $250 \mathrm{mg} / \mathrm{kgBB}, \quad 300 \mathrm{mg} / \mathrm{kgBB}$, dan $350 \mathrm{mg} / \mathrm{kgBB}$ dapat menurunkan kadar glukosa darah. Namun pada dosis $250 \mathrm{mg} / \mathrm{kgBB}$ memiliki efek yang lebih baik dari dua dosis lainnya, walaupun nilai $\Delta$ BSN-2PP pada dosis ini lebih kecil dari $\Delta$ BSN-2PP dari dosis $350 \mathrm{mg} / \mathrm{kgBB}$, tapi dosis $250 \mathrm{mg} / \mathrm{kgBB}$ dipilih menjadi dosis yang terbaik karena dari hasil statistik uji MannWhitney menunjukkan tidak terdapat perbedaan pada dosis $250 \mathrm{mg} / \mathrm{kgBB}$ terhadap kelompok kontrol normal (KN) ( $>>0,05), \quad$ sedangkan pada dosis $350 \mathrm{mg} / \mathrm{kgBB}$ menunjukkan terdapat perbedaan yang signifikan terhadap kelompok kontrol normal $(\mathrm{KN})(\mathrm{p}<0,05)$. Hal ini dapat diartikan, pada kelompok K1 (250mg/kgBB) memiliki efek menurunkan glukosa darah lebih baik dari kelompok K3 $(350 \mathrm{mg} / \mathrm{kgBB})$ karena nilai rerata $\Delta \mathrm{BSN}-$ 2PP K1 tidak memiliki perbedaan/mendekati nilai rerata kelompok normal $(\mathrm{KN})$. Nilai $\Delta$ yang semakin tinggi menunjukkan semakin banyak perubahan/penurunan kadar glukosa darah, hal ini berarti pada dosis $250 \mathrm{mg} / \mathrm{kgBB}$, terjadi perubahan kadar glukosa darah yang lebih efektif.

Hasil analisis uji regresi linier sederhana yang disajikan pada tabel 3 dan kurva dapat dilihat pada gambar 2 menunjukkan bahwa nilai $\mathrm{p}$ pada pengaruh dosis ekstrak etanol lidah buaya terhadap $\Delta$ BSN-2PP adalah $0,000 \quad(<0,05)$, hal ini menunjukkan bahwa dosis ekstrak etanol lidah buaya memiliki pengaruh yang bermakna terhadap $\Delta$ BSN-2PP. Konstanta dan koefisien persamaan regresi linier didapatkan $\mathrm{Y}=49,963+(-0,099) \mathrm{X}$. Dari hasil analisis diperoleh thit $=-4,979$, yang dimana perhitungan thit lebih besar dari tab, hal ini mengartikan ada pengaruh antara pemberian ekstrak etanol lidah buaya dengan
$\Delta$ BSN-2PP dengan arah kemaknaan negatif, semakin rendah dosis ektrak semakin tinggi $\Delta$ BSN-2PP. Nilai koefisien determinasi $\left(\mathrm{R}^{2}\right)$ hasil analisis adalah 0,488 , menunjukkan model persamaan linier tersebut adalah $48 \%$ benar.

\section{KESIMPULAN}

Pemberian ekstrak etanol lidah buaya pada dosis $250 \mathrm{mg} / \mathrm{kgBB}$ dapat mempengaruhi penurunan kadar glukosa darah pada tikus model hiperglikemia terinduksi streptozotocin.

\section{SARAN}

Perlu dilakukan penelitian lanjutan mengenai dosis $250 \mathrm{mg} / \mathrm{kgBB}$ ekstrak etanol lidah buaya untuk mengetahui tingkat keefektifan dan toksisitas pada dosis tersebut.

\section{DAFTAR PUSTAKA}

Alinejad-Mofrad, S., Foadoddini, M., Saadatjoo, S. A., \& Shayesteh, M., 2015. Improvement of glucose and lipid profile status with Aloe vera in pre- diabetic subjects: a randomized controlled-trial. Journal of Diabetes and Metabolic Disorders, 14(1), 22. https://doi.org/10.1186/s40200-0150137-2.

Beidokhti, M. N., \& Jäger, A. K., 2017. Review of Antidiabetic Fruits, Vegetables, Beverages, Oils and Spices Commonly Consumed in the Diet.

Journal of

Ethnopharmacology.https://doi.org/10.1 016/j.jep.2017.02.031. Cowsert, L. M. (2010). Biological Activities of Acemannan.

Damasceno, D. C., Netto, A. O., Iessi, I. L., Gallego, F. Q., Corvino, S. B., Dallaqua, B., Rudge, M. V. C. (2014). Streptozotocin-induced diabetes models: Pathophysiological mechanisms and fetal outcomes. BioMed Research International, http://dx.doi.org/10.1155/2014/81906 5 Retrieved from https://search.proquest.com/docview/ 1547916578 ? accountid=31533. 
DeFronzo R.A., 2004. Pathogenesis of Type 2 Diabetes Mellitus, The Medical Clinics of North America 88 (2004)787-835.

DOI:10.1016/j.mcna.2004.04.013.

Hastono S.P. dan Sabri L., 2011. Statistik Kesehatan, PT. RajaGrafindo Persada, Jakarta.

Jung J.Y., Lim Y., Moon M.S., Kim J.Y., Kwon O., 2011. Onion Peel Extracts Ameliorate Hyperglycemia and Insulin Resistance in High Fat Diet/Streptozotocin-Induced Diabetic Rats, Nutrition \& Metabolism, 8:18.

Joseph, B., \& Raj, S. J., 2010. Pharmacognostic And Phytochemical Properties Of Aloe Vera Linn - An Overview, International Journal of Pharmaceutical Sciences Review and Research, 4(2), 106-110.

Karunakaran, U., Park, S. J., Jun, D. Y., Sim, T., Park, K. G., Kim, M. O., Lee, I.K., 2015. Non-receptor tyrosine kinase inhibitors enhances $\beta$-cell survival by suppressing the PKC $\delta$ signal transduction pathway in streptozotocin - induced $\beta$-cell apoptosis. Cellular Signaling, 27, 1066-1074. http://dx.doi.org/10.1016/j.cellsig.2015. 01.018 .

Kementrian Kesehatan Republik Indonesia. 2011. Penyakit Tidak Menular Penyebab Kematian Terbanyak di Indonesia, diunduh 7 November 2017, jam $11.26 \quad$ WIB, $<$ http://www.depkes.go.id/index.php?v $\mathrm{w}=2 \% 25 \mathrm{id}=1637>$.

Kementrian Kesehatan Republik Indonesia. 2014. Situasi dan Analisis Diabetes, diunduh 7 November 2017, jam 11.30 WIB, <https://doi.org/24427659>.

Kemp, R.W., 2000. Handling and Restraint. The Laboratory Rat. Elsevier, Ch.3,3143.

Noor, A., Gunasekaran, S., \& Vijayalakshmi, M. A. 2017. Improvement of Insulin Secretion and Pancreatic $\beta$-cell Function in Streptozotocin-induced
Diabetic Rats Treated with Aloe vera Extract,Pharmacognosy Research.99105. https://doi.org/10.4103/pr.pr.

Revathy, C., Arun, M. D., \& Crispin, R. D., 2015. Molecular and CellularEndocrinology. https://doi.org/http://dx.doi.org/10.1016 /j.mce.2015.09.004.

Reza, S., Tabatabaei, F., Ghaderi, S., \& Bahrami-tapehebur, M. 2017.

Biomedicine \& Pharmacotherapy Aloe vera gel improves behavioral deficits and oxidative status in streptozotocininduced diabetic rats. Biomedicine \& Pharmacotherapy, 96(September), 279-290.

https://doi.org/10.1016/j.biopha.2017.0 9.146.

Rodríguez-González, V. M., Femenia, A., González-Laredo, R. F., RochaGuzmán, N. E., Gallegos-Infante, J. A., Candelas-Cadillo, M. G., Rosselló, C., 2011. Effects of pasteurization on bioactive polysaccharide acemannan and cell wall polymers from Aloe barbadensis Miller. Carbohydrate Polymers, 86(4), 1675-1683. https://doi.org/10.1016/j.carbpol.2011. 06.084 .

Sen, S., De, R. C., \& Biplab, D., 2016. Diabetes Mellitus in 21st Century.

Singapore: Springer Nature. https://doi.org/10.1007/978-981-101542-7.

Soonthornpun S., Rattarasarn C., Leelawattana R., Setasuban W., 1999. Postprandial Plasma glucose: a good index of glycemic control in type 2 diabetic patients having near-normal fasting glucose levels. Diabetes Research and Clinical Practice, 46 (1999) 23-37, DOI:10.1016/s01688227(99)00061-3.

Tanaka, M., Misawa, E., Ito, Y., Habara, N., Nomaguchi, K., Yamada, M., Higuchi, R., 2006. Identification of Five Phytosterols from Aloe Vera Gel as Anti-diabetic Compounds. Biological \& Pharmaceutical Bulletin, 29(7),1418-1422. https://doi.org/10.1248/bpb.29.1418. 
Jurnal Biosains Pascasarjana Vol. 20 (2018) pp

(C) (2018) Sekolah Pascasarjana Universitas Airlangga, Indonesia 